mandate, however, the courts should reach the same result, abandoning the unfortunate minority rule followed by the California court in the Dearo case.

\title{
THE GIFT AND LEASEBACK: A NEW TAX AVOIDANCE GIMMICK:
}

$\mathrm{By}$ one device after another wealthy breadwinners have sought to shift the apparent ownership of taxable income to family members in lower surtax brackets and still retain control of the transferred income or of the property producing it. ${ }^{1}$ Though the courts have defeated many of these attempts, they have never discarded the premise that each member of the family is an economic entity. Thus they have refused to tax the grantor on income transferred within his family unless he expressly reserves control of the income or its source.?

* Skemp v. Commissioner, 168 F.2d 598 (7th Cir. 1948); Brown v. Commissioner, 180 F.2d 926 (3rd Cir. 1950), cert. granted, 18 U.S.L. WeEK 3348 (Mfay 26, 1950).

1. Taxpayers have employed two kinds of devices to climb down the surtax ladder: those which split up income among family members; and those which establish deductible losses through transfers to family members. Income splitting has been attempted by joint ownership of income-producing property, c.g., McInerney v. Commissioner, 82 F.2d 665 (6th Cir. 1936) ; by assignment of income to persons who did not own the property or furnish the consideration for which the income was derived, c.g., Helvering v. Horst, 311 U.S. 112 (1940); Lucas v. Earl, 281 U.S. 111 (1930); by transfers of property which permit another member of the family to take a profit on a subsequent sale, e.g., Weil v. Commissioner, 31 B.T.A. 899 (1934), aff'd, 82 F.2d 561 (5th Cir. 1936), cert. denied, 299 U.S. 552 (1936); by compensation to family members for personal services, e.g., Biljac Holding Corp. v. Commissioner, 5 CCH Tax Ct. Rep. 857 (1946); by means of a family partnership, e.g., Commissioner v. Tower, 327 U.S. 280 (1946); Commissioner v. Culbertson, 337 U.S. 733 (1949); by gifts of stock in a family corporation, e.g., Byerly v. Commissioner, 154 F.2d 879, 880 (6th Cir. 1946), cert. denied, 329 U.S. 735 (1946); and by establishment of a family trust, e.g., Helvering v. Clifford, 309 U.S. 331 (1940).

Establishment of losses has been attempted by loans to impecunious family members on which a deduction is taken for bad debts, e.g., Thom v. Burnet, 55 F.2d 1039 (D.C. Cir. 1932) ; and by sale of property to family members at a loss. See IwT. Rev. Code $\$ 24$ (b) (1) (A); McWilliams v. Commissioner, 331 U.S. 694 (1947).

For fuller discussion of these devices see Burnet v. Wells, 289 U.S. 670, 675-677 (1933) ; Ryan, Federal Tax Treatment of the Family, 32 MAsg. L. Rev. 244 (1949), 33 MarQ. L. Rev. 1 (1949); Note, 47 Col. L. Rev. 665 (1947); Notc, 50 CoL. L. Rev. 68 (1950): Mannheimer, Income Tat Status of Gifts of Family Corporalion Stock, 25 TASES 604 (1947).

By paying a gift tax on the lifetime transfer of property under an income splitting device, taxpayers may also achieve estate tax savings. See note 26 infro. And where the taxpayer establishes losses to family members, he may even save a gift tax.

2. See e.g., Blair v. Commissioner, 300 U.S. 5 (1937). A much broader basis for taxing income to the donor was suggested by the Supreme Court in Helvering v. Horst, 311 U.S. 112 (1940). The taxpayer had transferred unmatured negotiable interest coupons from bonds held by him to his son who in turn collected the interest. Holding the donor taxable on the interest, the court declared that ". . . [the donor's] use of his economic 
This permits a well-to-do person to reduce his income tax without in fact changing his economic status. He simply makes a gift of stocks, bonds, or other income-producing property to family members, ${ }^{3}$ who use the income for purposes which he would have otherwise financed directly. ${ }^{4}$

A new clevice, recently sanctioned by two federal courts of appeals, offers the taxpayer a way to shift income to members of his family and still retain for his own use the income-producing property. In Skemp v. Commissioner, the taxpayer, a physician, conveyed his clinic building in trust ${ }^{6}$ income to be paid

gain, the right to receive the income, to procure a satisfaction which can be obtained only by the expenditure of money or property, would seem to be the enjoyment of the ittcome. ..."Id. at 117. Later decisions have not kept the Horst promise of satisfaction or enjoyment as a basis for taxation. Horst has been limited to situations where the donor retains control of the income-producing property. Pearce v. Commissioner, 315 U.S. 543, 554 (1942) ; Kohnstamm v. Pedrick, 153 F.2d 506, 508 (2d Cir. 1945).

Sections 166 and 167 INT. Rev. Code provide for taxing the settlor on income to revocable trusts or to trusts where the income may be used for his benefit. Helvering $v$. Clifford, 309 U.S. 331 (1940), presently stands as the broadest Supreme Court declaration on when trust income will be taxed to the settlor. The oft-discussed factors which the court felt were "relevant to the question of ownership" for income tax purposes were (1) the short duration of the trust (2) the fact that the settlor's wife was bencficiary (3) the settlor's control over the corpus. In view of these factors the court felt that there was merely a "temporary reallocation of income within an intimate family group. Since the income remains in the family and since the husband retains control over the investment, he has rather complete assurance that the trust will not effect any stbstantial change in his economic position." Id. at 335-336.

To provide more definite criteria for taxability in trust cases, the Treasury Department published the Clifford regulations in 1945. The regulations go beyond even the Clifford case. They tax the trust settlor on trust income, if the corpus or the income will return after a relatively short term of years; if the beneficial enjoyment of the corpus or income is subject to the grantor's power of disposition; or if the corpus or income is subject to administrative control exercisable for the benefit of the grantor. U.S. Treas. Reg. $111, \S 29.22(a)-21$ (1945).

The regulations do not expressly make family relationship between the settlor and beneficiary of the trust a factor upon which tax liability of the settlor depends. But cf. U.S. Treas. Reg. 111, \$29.22(a)-21(f) (1945). See generally, Eisenstein, The Clifford Regulations and the Heavenly City of Legislative Intention, 2 TAX L. REv. 327 (1947).

3. Section 51(b) INT. REv. Code provides for a husband-wife single tax return. It permits a married couple to minimize surtaxes by dividing their total income in half before computing the surtax and then multiplying the result by two. Thus the section climi-nates a good deal of incentive to intra-family tax avoidance. However, wealthy breadwinners can further divide their income by gifts to their children. The surtax is still "the inverse reward of fertility." Clapp v. Heiner, 51 F.2d 224, 225 (3rd Cir. 1931).

4. The donor may compel use of the income for his own purposes by economic or moral pressure on family members. He may just as effectively enjoy the income without express instructions as to its use, by donating it in lieu of funds he would otherwise have supplied-like an allowance. He will be taxed, though, on income employed to discharge a legal obligation to support his children. INr. REv. CODE $\$ 167$ (c) modifying Helvering v. Stuart, 317 U.S. 154, 170 (1942).

5. 168 F.2d 598 (7th Cir. 1948).

6. The building was worth over $\$ 40,000$. Brief for Petitioners, p. 22, Skemp v. Commissioner, 168 F.2d 598 (7th Cir. 1948). Settlor was probably taxable on the value of the 
monthly to his wife during her life and after her death to be used for the support and education of his children. Although the settler retained no formal control over the income, he did reserve an option to rent all or any part of the building at a rental to be determined by the trustee. ${ }^{7}$ On the very day the trust agreement was executed, the settlor exercised his option and leased back the entire trust property for ten years with the privilege of renewing the lease for another ten. 8 The lease provided that if the settlor died during its term, his executor had the right to cancel it.

During the taxable year the settlor paid $\$ 3,800$ as rentals to the trust. ${ }^{\circ}$ Of this amount the trustee paid out $\$ 2,850$ to the settlor's wife, who used the payments for "her health," travel, luxuries for herself, and luxuries and "things" for the children. ${ }^{10}$ There seems little doubt that the money turned over to the wife was used for the same purposes for which the settlor's own funds would have been used had he not created this arrangement."

In computing his income tax, the settlor deducted the rentals as business expenses of the taxable year. ${ }^{12}$ The commissioner asserted a deficiency, con-

property under the gift tax. See dissenting opinion, Skemp v. Commissioner, 8 T.C. 415, 422, 423 (1947).

7. The settlor also retained power to veto the sale or mortgage of the trust property, and the right to direct the trustee to retain or sell any trust property. The trust agreement further provided that the trustee is under "no liability for any loss arising from any action taken or omitted to be taken at the direction of the settlor." Skemp v. Commissioner, 8 T.C. 415,417 (1947).

8. Rent for the first two years was fixed at $\$ 500$ a month. Thereafter it was to be determined by the trustee and the settlor. In the event of disagreement between them, it was to be fixed by an arbitrator.

Under the lease the trust was bound to make all necessary repairs on the building and to maintain the exterior. The taxpayer had to provide janitor service, heat, light and water for the building and to pay for the insurance and taxes. S T.C. $415,418-19$ (1947).

9. 8 T.C. 415,419 (1947).

10. Brief for Respondent, pp. 18-19, Skemp v. Commissioner, 168 F.2d 593 (7th Cir. 1948), quoting from Mirs. Skemp's testimony before the Tax Court.

Mrs. Skemp was not given instructions either by the settlor or the trustee as to how the money was to be used. In fact, at the time of the hearing she had never seen the trust agreement and did not know of its terms. Skemp v. Commissioner, 8 T.C. 415,419 (1947).

11. In 1941 the settlor's total income was $\$ 59,919.61$ and his net income $\$ 29,503.90$. In 1943 the settlor's net income was $\$ 42,08 s .88$. Skemp v. Commissioner, 8 T.C. 415,419 (1947). Since the Tax Court found that Mrrs. Skemp was in poor health and that she had to travel to recuperate, it seems a fair inference that the settlor would have supplied the money necessary for her health if there were no trust income. Similarly, the settlor probably would have underwritten luxury expenses in the absence of this arrangement.

12. The taxpayer claimed a deduction under $\$ 23(a)$ of the Irr. REv. CoDE which provides for a deduction of "All the ordinary and necessary expenses paid or incurred during the taxable year in carrying on any trade or business, including . . . rentals or other payments required to be made as a condition to the continued use or possession, for purposes of the trade or business, of property to which the taxpayer had not taken or is not taking title or in which he has no equity."

The original statute, 39 Stax. 759 (1916) provided "there shall be allowed as deductions-First. The necessary expenses actually paid in carrying on any business or trade. ..." The statute was changed to its present form in 1919. 
tending that the rentals were not deductible. ${ }^{13}$ The Tax Court, upholding the commissioner, pointed out that the settlor had placed the property in trust on condition that he could get back use of the property by promising to make a series of periodic payments. Since he got the use of the property back, he merely gave his promise to make the periodic payments; and while the promise might be legally binding, the payments were really gratuitous and hence not deductible. ${ }^{14}$ But the seventh circuit court of appeals reversed, holding that the rentals satisfied the statutory test of deductibility because they were "required" for the continued use of the property. ${ }^{15}$

An alternative use of the gift and leaseback is illustrated by Brown v. Commissioner..$^{10}$ The facts were essentially the same as those in the Skcmp casea gift of property in trust on condition that it could be leased back by the settlors. ${ }^{17}$ In the Brozen case, however, income to the trust was not to be paid out until the beneficiaries reached their majority; there was thus no possibility that the settlor would be able to control the use of the income in the near firture. ${ }^{18}$ The commissioner argued that rentals and royalties paid under the leaseback were not deductible by the settlors for, as he pointed out, their aim was merely to make periodic gifts to their children. ${ }^{10}$ The Tax Court sustained

13. The Commissioner permitted Skemp to deduct $\$ 689.94$ for depreciation on the trust property. But he claimed a deficiency of $\$ 1,679.43$. The claim was based on three grounds: first, that no gift of the property had in fact been made (discussed more fully infra); sccond, that the settlor retained sufficient dominion and control over the trust property that he could be treated as the owner of the property under the Clifford and Shart doctrines; and third, that the income should be taxed to the settlor because it was used to discharge his legal obligation to maintain his wife. See note 4 supra. The Tax Court did not consider the last two grounds. 8 T.C. 415,420 (1947). The court of appeals, in reviewing the Tax Court's decision, also ignored them.

14. 8 T.C. $415,420-421$ (1947). Judge Black dissented from the majority opinion. He was impressed by the fact that the trustee was an independent corporation, that the $\$ 500$ rentals were fair, and that the conveyance to the trust was beyond the settlor's recall.

15. 168 F.2d 598,600 (7th Cir. 1948). The court noted that "required" rental payments were deductible, and unless violation of a fiduciary duty was to be imputed to the trustec, the taxpayer was "required" to pay the monthly sums. Furthermore, the court was convinced that the taxpayer's economic status had been changed by the gift. Since the rent went into the wife's individual bank account, "of course [it] is her separate property."

16. 180 F.2d 926 (3rd Cir. 1950). Certiorari has been granted. 18 U.S.L. WEEK 3348 (May 26, 1950).

17. The settlors were a husband and wife engaged as partners in a coal mining business. The trust corpus was composed of two properties : 8.9 acres of land upon which was located a railroad siding used for transporting the settlors' coal; and 35 acres of coal land.

In the Brozen case, unlike the $S k e m p$ situation, the trust agreement itself contained no provision for the leaseback. But the properties were transferred to the trustee with the understanding that they were to be leased back to the taxpayers, who would continue to operate them as a partnership. Brown v. Commissioner, 180 F.2d 926, 927 (3rd Cir. 1950).

18. The trustee did have full discretion to pay out of the income sums necessary for the support, maintenance and education of any of the beneficiaries.

19. Gifts to family members are not deductible. INT. REv. CODE $\$ 23(0)$. In addition to rentals deducted by the taxpayers, the commissioner included in their income $\$ 26$ rent 
the commissioner, expressly declining to follow the seventh circuit's decision in the Skemp case. ${ }^{20}$ But the third circuit, relying on the Slemp rationale, reversed the Tax Court and upheld the deductions. ${ }^{21}$

In finding the rentals under a gift and leaseback deductible, the $S$ licmp decision opens the floodgates to intra-family tax avoidance. This device can now be used for tax reduction by the many people who have no expendable incomeproducing property. The avoidance-minded taxpayer need only make a conditional gift ${ }^{22}$ of property useful in his business-be it land, buildings, automobiles, or machinery. ${ }^{23}$ By exercising his option to lease back the property, he secures the full enjoyment of it for as long as he wishes, ${ }^{24}$ and at his death

paid by another person who used the railroad siding during the taxable year. The taxpayers had paid this money to the trustee.

20. 12 T.C. 1095 (1949). Judge Arundell dissented on the ground that the case was controlled by the Skemtp decision.

The Tax Court majority felt that the gift and the leasebsck were a single integrated transaction. They pointed out that "for income tax purposes, if A purports to give B $\$ 10,000$, with the understanding that $B$ will buy 100 shares of $X$ stock from $A$, and $B$ does so, ... [a] single integrated transaction occurred and that was not a gift of $\$ 10,000$ from $A$ to $B$, but a gift of 100 shares of $X$ stock:" Similarly they felt that the gift and leaseback were interdependent. "Petitioners never intended to and in fact never did part with their right to mine coal from the acreage and load and ship the same from the siding, which they transferred to the trusts. They merely intended and made a gift of their partnership income in the amounts of the contested 'rents' and 'royalties' to the trusts for their children." 12 T.C. 1095 (1949).

21. Judge Kalodner dissented. He contended that the Tax Court's decision that the rents and royalties paid by settlors were in reality gifts of partnership income was a factual conclusion. It was therefore not to be disturbed unless "clearly crroneous" under INT. REv. CODE $\$ 1141$ (a). This section made Tax Court decisions reviewable by circuit courts to the same extent that district court decisions are under FED. R. CIv. P. 52(a). See Commissioner v. Penn Athletic Club, 176 F.2d 939, 943 (1949). Since the findins of the Tax Court was supported by evidence which permitted at most conflicting interferences, he considered.it conclusive.

Treating the Tax Court's holding as a decision of law based on evidentiary facts which were not in issue seems more reasonable. The courts are not clear on the point. Compare Madeira v. Commissioner, 98 F.2d 556, 557 (3rd Cir. 1938) wiilh Aranning v. Gagne, 108 F.2d 718 (1st Cir. 1939). See also Wichita Terminal Elevator Co. v. Commissioner, 162 F.2d 513, 515 (10th Cir. 1947).

22. Although the Skemp and Broun rationales would logically be applieable to a gift made directly to family members as well as to a gift in trust, the latter form will probably withstand judicial scrutiny more effectively. The two circuit courts were themselves impressed by the fact that there were independent trustees involved. Skemp v. Commissioner, 168 F.2d 598, 600 (7th Cir. 1948) ; Brown v. Commissioner, 180 F.2d 926, 929 (3rd Cir. 1950).

23. Any property used "for purposes of trade or business" would satisfy $\$ 23(a)(1)$ (A). Exercising a little imagination, most persons could find some property of that description which they can give away and lease back.

24. In the Skemp case enjoyment was reserved for twenty years. It may also be re" served until the death of the settlor. If the property involved is a wasting asset, like the Brown coal mines, it can be leased back for a period long enough to exhaust the asset. This was the stated aim of the Browun settlors. See dissenting opinion of Judge Kalodner, Brown v. Commissioner, 180 F.2d 926, 930 (3rd Cir. 1950). 
it is retained by family members who would normally have received it as his testamentary beneficiaries. Thus, with only slight change in his economic position, the taxpayer reduces his taxable income by paying deductible rentals from one pocket to another. ${ }^{25}$ And even where the taxpayer fully intends to pay the rentals to a different pocket, as in the Brozen case, he still achieves tax savings. Since the gift and leaseback does not require that he part with the use of the property, his rental payments are, in effect, deductible gifts to family members. ${ }^{26}$

Concerned with the superficialities of the transaction, the two courts of appeals found that the settlors were "required" to make the periodic rental payments. But the settlors were liable for the payments only because they voluntarily placed the property in trust and did not reserve a rent-free leasehold. Rentals purposely provided for to achieve tax savings can hardly be considered "required."27

The Tax Court's appraisal of the gift and leaseback is far more realistic. Family taxation has been treated by the courts as a practical matter concerned with economic fact rather than with legal title and legal technicalities. ${ }^{28}$ They have consistently eliminated formal steps in otherwise integrated transactions and have disregarded the conduits which would render the transactions tax-

25. Unless rentals are large enough to cut down surtax, the taxpayer may find that he has paid more in a gift tax than he has saved in income tax. But where the rentals are unreasonably high, the court may be more willing to find that they are gifts, $c f$. clissenting opinion, Skemp v. Commissioner, 8 T.C. $415,422-423$ (1948), or at least will limit the deduction to a reasonable amount. $C f$. Limericks, Inc. v. Commissioner, 165 F.2d 483 (5th Cir. 1948).

26. Whether or not he controls the rentals, by making a lifetime gift rather than testamentary transfer of the property, the taxpayer can achieve estate tax savings. Since the estate tax base and gift tax base are independent, the property which would be stbject to the highest estate tax if retained till death is removed to the lower gift tax brackets. Moreover, the gift tax allows a separate exemption of $\$ 30,000$ as well as annual cxclusions of $\$ 3,000$ for each donee. This means more savings by lifetime transfer. Finally, while the amount paid out as under the estate tax is part of the base on which the tax is computed, the amount paid as a gift tax is not included in the taxable estate.

By making a gift rather than a transfer at death, however, the taxpayer does lose the advantages of INT. REv. Code $\S 113(a)(5)$. This section provides that the tax basis of property acquired by testamentary transfer in the hands of the transferce is the fair market value at the time of acquisition. Thus by waiting until death to transfer his property, the taxpayer can save his transferees a capital gains tax on the property appreciation during his lifetime.

27. The courts have frequently asserted that income tax deductions are matters of legislative grace and the burden of showing the right to the claimed deduction is on the taxpayer. See, e.g., Interstate Transit Lines v. Commissioner, 319 U.S. 590, 593 (1943). The mere fact that expenses are incurred as a result of contractual obligation does not make them deductible. "The origin and nature, and not the legal form, of the expense sought to be deducted determines the applicability of the words of $\$ 23(\mathrm{a}) . "$ Id. at 594 . See also Deputy v. duPont, 308 U.S. 488, $494-497$ (1940). In view of their origin, these expenses can hardly be considered "required."

28. See Higgins v. Smith, 308 U.S. 473, 477-478 (1940). 
exempt. ${ }^{29}$ In Jolnuson $v$. Commissioncr, ${ }^{30}$ for example, the taxpayer gave money to his wife which she placed in trust to be loaned back to him. The second circuit court of appeals held that interest which the taxpayer paid to his wife via the trustee was not deductible as a business expense. It decided that the husband had not made a gift in the first place, since he only gave the money to his wife to be loaned back to him. He merely made a gratuitous promise to pay "interest." 31 The Jolnnson reasoning is applicable to the gift and leaseback device. To make a valid gift, the donor must intend to part with the property absolutely. Without such intent, the gift must fail.

Undoubtedly, the most practicable solution to the problem of intra-family tax avoidance lies in legislative enactment requiring some form of return based on total family income. ${ }^{32}$ Until such legislation is forthcoming, the courts are

29. See, e.g., McWilliams v. Commissioner, 331 U.S. 694 (1947) (deduction for loss on exchange sale of stock is forbidden by $\$ 24(b)$ as a loss from "sales or cxchanges of property, directly or indirectly ... between members of a family," if at time husband sells on exchange, broker buys same kind of stock for wife's account).

Ingle Coal Corporation v. Commissioner, 174 F.2d 569 (7th Cir. 1949) presents an interesting sequel to the Skemp case. The Ingle Coal Company, a closely held family corporation, distributed its assets to its stockholders. They in turn transferred them to the newly formed Ingle Coal Corporation. In return for the assets the Corporation agreed to assume the liabilities of the Company and to pay the stockholders a royalty of $\$ .05$ for each ton of coal mined. The Corporation then deducted royalty payments under $\$ 23(a)$. The Commissioner's claim that they were not deductible was upheld by the Tax Court on the ground that the payments were in substance a dividend distribution. 10 T.C. 1199 (1948). Upholding the Tax Court, the seventh circuit court of appeals found that the royalty payments were dividend payments. But even if they were assumed to be expenses, they were not "necessary" expenses-for the company had the right to mine the coal without paying royalties to its stockholders. The imposition of the royalties was thus not necessary for the continuance of its business. The court tried to distinguish the Skentp case on the ground that in that case "there was a change in the taxpayer's status; ... he could only continue to occupy the building by paying the amount of rent fixed by the trustee. In the case before us the transfer of property was not to an independent third party but to a corporation which the same stockholders controlled, and who had it within their power to change or erase the overriding royalty obligations at any time they chose."

30. 86 F.2d 710 (2d Cir. 1936).

31. See also, Elbert v. Commissioner, 45 B.T.A. 685 (1941); cf. Guaranty Trust Co. of New York v. Commissioner, 98 F.2d 62 (2d Cir. 1938). But cf. Preston v. Commissioner, 132 F.2d 763, 765 (2d Cir. 1942).

32. Two kinds of family return have been suggested; a mandatory joint return, or a per capita return. The mandatory joint return would require that family carnings be totaled and that the surtax be computed at a rate applicable to the sum. The per capita return would extend present husband-wife income splitting to children. See note 3 sspro. Tax rates would of course be raised to make up the lost income.

The mandatory joint return has too many opponents to make it politically feasible. A similar system of income taxation, attempted in Wisconsin, was declared unconstitutional by the Supreme Court. Hoeper v. Tax Commission of Wisconsin, 234 U.S. 206 (1931). See Note, 10 Geo. Wash. L. Rev. 954 (1947); Surrey, Family Ineome and Fcderal Taxation, 24 TAXES 980, 984-986 (1946). It is unlikely, however, that that decision would be followed today. 